\title{
MODEL PENDUGA VOLUME POHON NYAWAI (Ficus variegata Blume) DI KALIMANTAN TIMUR
}

\author{
(Tree Volume Estimation Model for Ficus variegata Blume in East Kalimantan) \\ Muhammad Abdul Qirom dan Supriyadi \\ Balai Penelitian Kehutanan Banjarbaru \\ Jl. Ahmad Yani Km. 28,7 Landasan Ulin \\ Banjarbaru 7074 Kalimantan Selatan \\ Telp./Fax. 0511-4707872 \\ Email:qirom_ma@yahoo.co.id
}

Naskah masuk : 4 Januari 2013; Naskah diterima : 20 November 2013

\begin{abstract}
Ficus variegata Blume has only recently developed for the development of plantation forest. Estimation of this potential requires an accurate instrument, but such instrument is not yet available. Tree volume is determined by Spiegel Relaskop Bitterlich. This study was intended to find the best model for estimating tree volume and potential stands of nyawai at PT. ITCI-Kartika Utama East Kalimantan. The estimation model used linear and non-linear models. The best model was determined by using statistical parameters. It was found that the best model of tree volume estimation used the diameter and height as its independent variables. The inclusion of height into the model estimation increased the accuracy and precision of estimation compared to the models with single variable. The potential volume ranged from $21.66 \mathrm{~m}^{3} / \mathrm{ha}-113.56 \mathrm{~m}^{3} / \mathrm{ha}$ at the ages of 4-7 years. The model can be applied to a population with similar characteristics of growing location.
\end{abstract}

Keyword: Nyawai, model, volume, potential, spiegel

\begin{abstract}
ABSTRAK
Jenis nyawai baru dikembangkan untuk pengembangan hutan tanaman. Pendugaan potensi ini memerlukan instrumen penduga volume yang tepat. Namun, instrumen tersebut belum tersedia. Volume pohon ditentukan dengan Spiegel Relaskop Bitterlich (SRB) sehingga pohon-pohon contoh tidak ditebang. Penelitian ini bertujuan mendapatkan model penduga volume terbaik dan menduga potensi tegakan nyawai di PT. ITCI-Kartika Utama Kalimantan Timur. Penyusunan model penduga volume menggunakan model linear dan non linear dengan peubah tunggal diameter, dua pubah (diameter dan tinggi), dan kombinasi diameter dengan tinggi. Model terbaik ditentukan menggunakan parameter statistik antara lain: standar error, signifikasi parameter dugaan, koefisien determinasi terkoreksi ( ${ }^{2}$ adj), Root Mean Square Errors, Akaike Information Criteria (AIC), simpangan relatif dan agregatif, dan bias. Model terbaik penduga volume menggunakan diamater dan tinggi sebagai peubah bebasnya dengan persamaan: Ln Volume $=-9,22846+1,7456 \mathrm{Ln}$ (Diameter) + 0,9759Ln (tinggi). Penambahan tinggi dalam penyusunan model penduga volume meningkatkan akurasi dan ketepatan dugaan dibandingkan model dengan peubah tunggal. Namun demikian, berdasarkan pertimbangan kepraktisan di lapangan, persamaan dengan variabel diameter yaitu: $V=0,00073 D^{2,0051}$ dapat digunakan. Model tersebut hanya digunakan dan hanya berlaku pada kondisi iklim dan tempat tumbuh yang sama. Potensi volume pohon berkisar antara $21,66 \mathrm{~m}^{3} / \mathrm{ha}-113,56 \mathrm{~m}^{3} / \mathrm{ha} \mathrm{untuk}$ umur 4-7 tahun. Model penduga volume yang telah disusun dapat diterapkan pada tegakan dengan karakteristik tempat tumbuh hampir sama.
\end{abstract}

Kata kunci: Nyawai, model, volume, potensi, spiegel 


\section{PENDAHULUAN}

Ficus spp. termasuk jenis-jenis utama penyusun hutan tropika selain jenis-jenis meranti. Jenis-jenis Ficus spp. digunakan untuk penanaman pohon pada program restorasi hutan di Thailand (Kuaraksa et al., 2012). Jenis-jenis Ficus spp. tersebut antara lain Ficus auriculata, F. fulva, $F$. hispida, F. oligodon, F. semicordata, F. triloba, dan F. variegata (Kuaraksa et al., 2012). Ficus variegata Blume atau nyawai termasuk jenis pohon pioner dan umumnya mempunyai akar berbanir pada waktu dewasa (Spencer et al., 1996; Kuaraksa et al., 2012). Pada pohon dewasa, buah fig (ara) terdapat pada bagian cabang utama dan batang (Spencer et al., 1996; Kuaraksa et al., 2012).

Jenis nyawai termasuk jenis dengan daur pendek (daur $<10$ tahun) dan mempunyai riap ratarata volume mencapai lebih dari $20 \mathrm{~m}^{3} / \mathrm{ha} /$ tahun pada umur 8 tahun (Badan Litbang Kehutanan, 2010). Berdasarkan kondisi tersebut, jenis ini sangat potensial dikembangkan untuk pembangunan hutan tanaman (Badan Litbang Kehutanan, 2010). Saat ini, hutan tanaman nyawai telah dikembangkan oleh PT. ITCI-Kartika Utama Kalimantan Timur. Hutan tanaman ini dikembangkan dalam rangka proyek Pembangunan Manajemen Unit Model Hutan Meranti (PMUMHM) bersama Kementerian Kehutanan. Oleh karena itu, pengembangan nyawai membutuhkan informasi yang lengkap tentang kondisi tegakan, pertumbuhan, dan hasil yang diperoleh pada masa yang akan datang.

Pendugaan hasil tegakan memerlukan metode yang akurat, efisien, dan handal (Arevelo et al., 2007). Secara umum, pendekatan yang digunakan adalah model alometrik penduga volume. Model penduga volume untuk mendapatkan potensi tegakan berupa kayu (Snorrasson and Einarsson, 2006). Menurut Zianis et al. (2005) sebagian besar negara Eropa mempunyai model penduga volume yang digunakan dalam penge- lolaan sumber daya hutan. Penggunaan ekstrapolasi dari suatu model alometrik volume menyebabkan pendugaan terhadap volume tidak akurat (Suchomel et al., 2012). Keakuratan dan ketepatan suatu model alometrik dapat ditingkatkan dengan menyusun model alometrik yang bersifat spesifik (Brandies et al., 2006) baik jenis atau klon, umur, dan tempat tumbuhnya (Arevelo et al., 2007).

Penyusunan model alometrik ini menggunakan diameter, tinggi dan kombinasi dari kedua dimensi tersebut sebagai peubah bebas untuk menduga volume pohon jenis nyawai. Tahapan penyusunan model alometrik terdiri dari beberapa tahapan yakni: penyelarasan data menggunakan beberapa model alometrik, kriteria statistik, kelogisan model berdasarkan grafik antara lain: bentuk dan konsistensi grafik, mencakup keseluruhan data (Suchomel et al., 2012) dan kriteria biologi (Subedi and Sharma, 2012). Tujuan penelitian adalah untuk mendapatkan model penduga volume terbaik dan menduga potensi jenis nyawai di PT. ITCI-Kartika Utama. Model ini digunakan menyusun tabel volume lokal dan standar jenis nyawai di Kalimantan Timur. Model ini sebagai alat yang mudah mendapatkan potensi tegakan jenis nyawai secara cepat dan akurat.

\section{METODE PENELITIAN}

\section{A. Lokasi penelitian}

Penelitian dilakukan di areal PT. ITCI-Kartika Utama Kalimantan Timur. Areal penelitian ini mempunyai topografi yang datar dengan kemiringan $<8 \%$. Jenis tanah termasuk dalam kelompok Podsolik Merah Kuning dengan $\mathrm{pH}$ antara 4,7-5,3 (Qirom dan Supriyadi, 2012a). Secara geografis, areal ini terletak pada $116^{\circ} 32^{\prime} 2,83^{\prime \prime} \mathrm{BT}$ dan $0^{\circ} 51^{\prime} 37,49^{\prime \prime}$ 'LS (Gambar 1). Pengambilan data dilakukan pada bulan April dan Nopember 2012. 


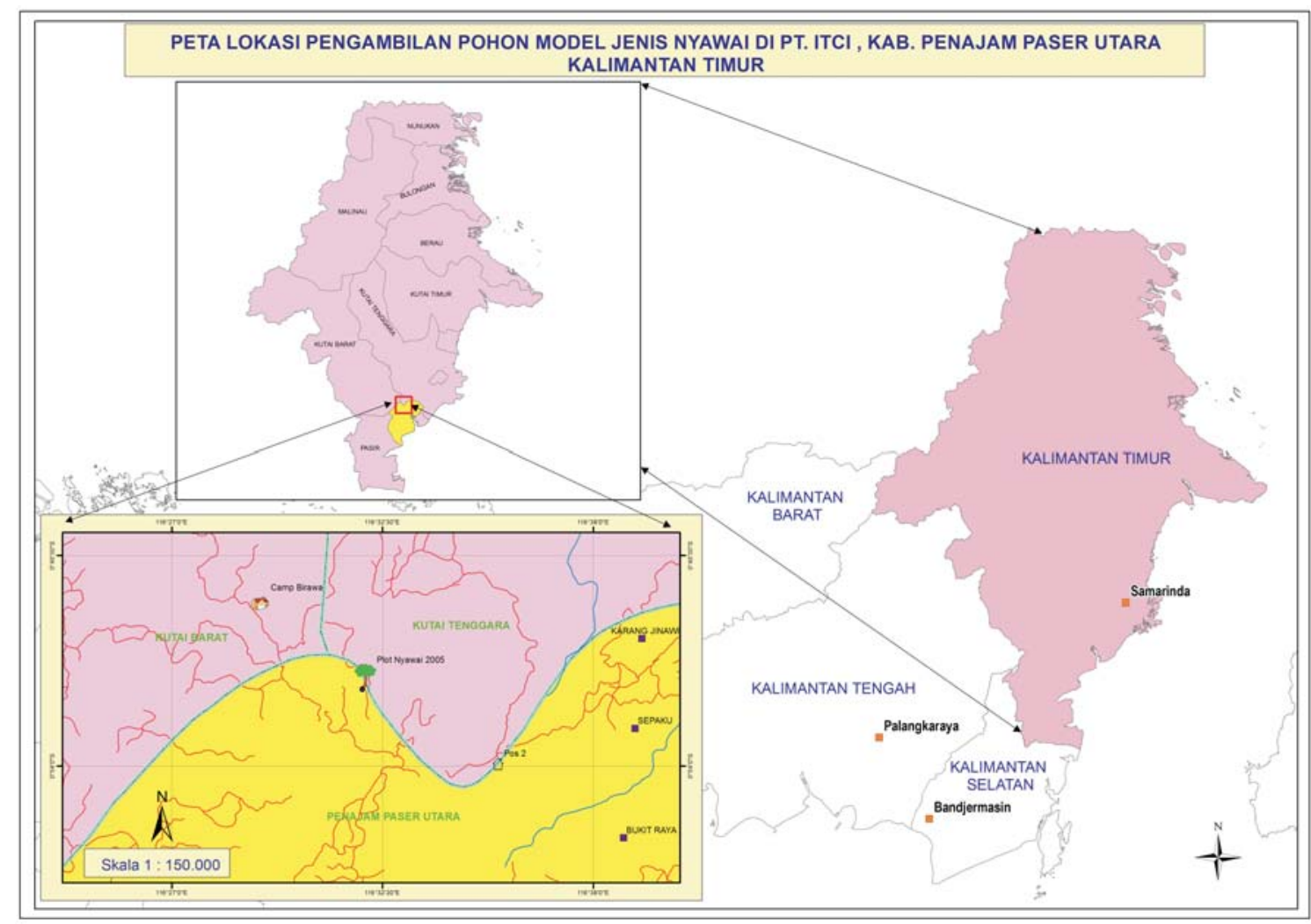

Gambar (Figure) 1. Peta lokasi penelitian (Map of study site)

\section{B. Pengambilan Pohon Contoh dan Penguku- ran}

Pohon contoh harus dapat menggambarkan kondisi tegakan secara keseluruhan sehingga pertimbangan yang digunakan dalam penentuan pohon contoh yakni keterwakilan dari tegakan. Keterwakilan ini ditunjukkan dari beberapa parameter yakni ketersebaran dimensi tegakan dan kondisi tempat tumbuhnya (Subedi and Sharma, 2012). Pertimbangan yang digunakan dalam pe- nentuan pohon contoh antara lain pohon sehat, tidak cacat, dan bebas dari gangguan per-tumbuhan (Subedi and Sharma, 2012). Pohon-pohon contoh yang terpilih mempunyai sebaran diameter antara 18,5-49,4 cm dan tinggi antara 14,724 meter. Frekuensi masing-masing kelas diameter pohon untuk penyusunan dan validasi model volume seperti pada Tabel 1. Secara umum, pohon contoh mempunyai bentuk yang relatif silinder dengan angka bentuk lebih dari 0,5 (Gambar 2).

Tabel (Table) 1. Frekuensi pohon model berdasarkan kelas diameter (Frequency of tree model based on diameter class)

\begin{tabular}{ccrcc}
\hline \multirow{2}{*}{ No } & Kelas diameter & \multicolumn{3}{c}{ Pohon model } \\
\cline { 3 - 5 } & & Total & Penyusunan & Validasi \\
\hline 1. & $18,5-22,5 \mathrm{~cm}$ & 33 & 20 & 13 \\
2. & $22,5-26,5 \mathrm{~cm}$ & 44 & 26 & 18 \\
3. & $26,5-30,5 \mathrm{~cm}$ & 18 & 11 & 7 \\
4. & $30,5-34,5 \mathrm{~cm}$ & 2 & 1 & 1 \\
5. & $34,5-38,5 \mathrm{~cm}$ & 1 & 1 & 1 \\
6. & $38,5-42,5 \mathrm{~cm}$ & 0 & 1 & 0 \\
7. & $42,5-46,5 \mathrm{~cm}$ & 1 & 0 & 0 \\
8. & $46,5-50,5 \mathrm{~cm}$ & 101 & 1 & 0 \\
\hline
\end{tabular}


Dimensi pohon contoh yang diukur yakni diameter setinggi dada (dbh) dan tinggi total. Pengukuran diameter dan tinggi total menggunakan pita ukur diameter dan haga meter. Pengukuran diameter dilakukan pada pohon berdiri (non-destructive) sehingga pohon-pohon contoh tidak ditebang. Pengukuran ini meng-gunakan spiegel relaskop bitterlich (SRB) (Qirom dan Supriyadi, 2012b; Susanty et al., 2006). SRB ini merupakan alat optis sehingga diameter tidak dapat ditentukan secara langsung. Diameter pengukuran ditentukan berdasarkan rumus: (Bitterlich,1990)

$$
\mathrm{d}(\mathrm{cm})=\mathrm{H} *(\mathrm{~L}+0,25 *(\mathrm{~S}+\mathrm{s})) * 2
$$

Keterangan (Remarks): d (cm): diameter; H: jarak pengukuran; L: nilai 0 atau 1 ; $\mathrm{S}$ : nilai $0,1,2,3$, dan 4 ; s: nilai 0,2 (masuk di band kecil), 0,4 (masuk di setengah band), 0,6 (masuk lebih dari setengah band), 0,8 (hampir memenuhi band).
Volume pohon total ditentukan dengan penjumlahan sortimen-sortimen pohon. Panjang sortimen pohon sepanjang 2 meter. Volume per sortimen pohon menggunakan rumus Smalian (Husch, 1963):

$$
\text { Vs } \frac{\mathrm{Bu} B p}{2} \times L
$$

$\mathrm{V}_{\mathrm{p}} \quad \mathrm{Vs}$

Keterangan(Remarks): Vs: Volume per seksi $\left(\mathrm{m}^{3}\right)$; $\mathrm{Bu}$ : luas bidang dasar ujung sortimen $\left(\mathrm{m}^{2}\right)$; $\mathrm{Bp}$ : luas bidang dasar pangkal sortimen $\left(\mathrm{m}^{2}\right)$; L: panjang sortimen $(\mathrm{m})$; $\mathrm{Vp}$ : volume pohon $\operatorname{contoh}\left(\mathrm{m}^{3}\right)$.

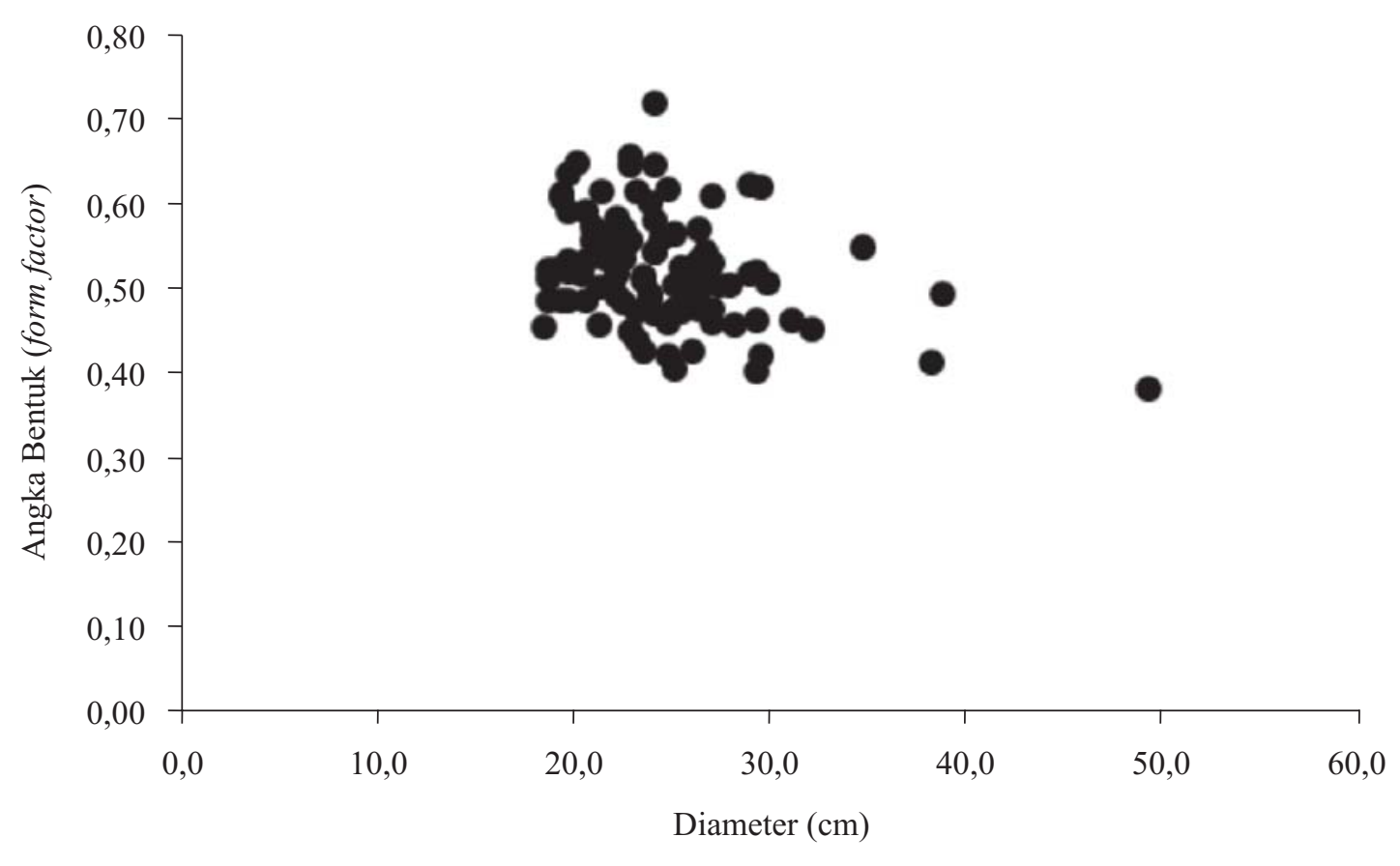

Gambar (Figure) 2. Hubungan antara angka bentuk pohon dengan diameter (Relationship of form factor and diameter) 


\section{Analisis Data}

\section{Keeratan hubungan antara diameter, tinggi dan volume pohon}

Keeratan hubungan antara variabel ditentukan dengan korelasi pearson (r). Nilai $r$ ini menunjukkan tingkat keeratan hubungan antar variabel (tinggi dan diameter) sehingga semakin tinggi nilai $r$ menunjukkan hubungan antar variabel semakin erat.

\section{Penyusunan persamaan regresi}

Pendekatan yang umum digunakan dalam penentuan persamaan regresi yakni metode kuadrat terkecil (Ordinary least square: OLS) (Subedi and Sharma, 2012; Brandies et al. 2006; Zianis et al., 2005). Hubungan antara volume dengan diameter, tinggi, dan kombinasi diameter dengan tinggi diasumsikan mempunyai hubungan yang linear dan non-linear sehingga model penduga volume adalah fungsi dari $\mathrm{V}=\mathrm{f}(\mathrm{D}, \mathrm{b}) ; \mathrm{V}=\mathrm{f}$ $(\mathrm{D}, \mathrm{H}, \mathrm{b})$; dan $\mathrm{V}=\mathrm{f}(\mathrm{DH}, \mathrm{b})$ atau $\mathrm{V}=\mathrm{f}\left(\mathrm{D}^{2} \mathrm{H}, \mathrm{b}\right)$. Pada penelitian ini, data-data hasil pengukuran (diameter, tinggi) dicobakan pada beberapa model alometrik. Model-model alometrik tersebut antara lain:
(E1) $\mathrm{V}=\mathrm{a} \mathrm{D}^{\mathrm{b}}$
(Zewdieet al., 2012; Bras- sard et al., 2011; Turski et al. 2008; Arevalo et al., 2007; Brandies et al., 2006)
(E2) $\mathrm{V}=\mathrm{a}+\mathrm{bD}^{2} \mathrm{H}$........... (Zewdie et al., 2012; Mon- tagu et al., 2005)
(E3) $\mathrm{V}=\mathrm{ab}^{\mathrm{D}}$.................... (Turski et al. 2008; Brandies et al.2006)
(E4) $\mathrm{V}=\mathrm{a}+\mathrm{bD}+\mathrm{cD}^{2} \ldots . . . \quad$ (Turski et al., 2008)
(E5) $\mathrm{V}=\mathrm{aD}^{\mathrm{b}} \mathrm{H}^{\mathrm{c}}$............. (Zewdie et al., 2012; Bras- sard et al., 2011; Brown et al., 1989; Brown, 1997)
(E6) $\mathrm{V}=\mathrm{a} \exp \left({ }^{-b} / \mathrm{D}\right) \ldots \ldots$ (Subedi and Sharma, 2012)
(E7) $\mathrm{V}=\mathrm{a}^{*} \exp (\mathrm{bD}) \ldots \ldots . . . \quad$ (Subedi and Sharma, 2012)
(E8) $\mathrm{V}=\mathrm{a}\left(\mathrm{D}^{2} \mathrm{H}\right)^{\mathrm{b}}$............. (Zewdie et al., 2012; Lima et al., 2012; Brandies et al. 2006)
(E9) $\ln \mathrm{V}=\mathrm{a}+\mathrm{b} \ln (\mathrm{D}) \ldots . \quad$ (Lima et al., 2012; Bran- dies et al., 2006; Akinni- fesi and Akinsami, 1995)
(E10) $\ln \mathrm{V}=\mathrm{a}+\mathrm{b} \ln (\mathrm{D})+\mathrm{c} \ln (\mathrm{H}) \ldots($ Lima et al., 2012; Akinnifesi and Akinsami, 1995)

Keterangan(Remarks): V: volume $\left(\mathrm{m}^{3}\right)$; D: diameter setinggi dada $(\mathrm{cm})$; $\mathrm{H}$ : tinggi pohon (m); a,b,c: parameter persamaan

\section{Evaluasi model penduga}

Evaluasi model volume ditentukan dengan beberapa kriteria yakni: (1) standar eror (Suchomel et al., 2012; Zewdie et al., 2009), (2) signifikansi dari parameter dugaan $(\mathrm{p}<0,05)$ (Suchomel et al., 2012; Zewdie et al., 2009), (3) Root Mean Square Errors (RMSE) untuk mengetahui akurasi model (Subedi and Sharma, 2012), (4) koefisien deter-minasi terkoreksi $\left(\mathrm{R}_{\text {adj }}^{2}\right)$ (Subedi and Sharma, 2012; Suchomel et al., 2012; Zewdie et al., 2009), (5) Akaike Information Criterion (AIC) untuk membandingkan beberapa model penduga volume (Subedi and Sharma, 2012; Basuki et al., 2009), (6) Simpangan relatif $(\mathrm{SR}<10 \%)$ dan Agregatif (SA $<1 \%)$ (Spurr, 1952), dan (7) bias dugaan (Laar and Akca, 1997).

\section{HASIL DAN PEMBAHASAN}

\section{A. Hasil}

\section{Variasi pohon contoh}

Penyusunan dan validasi model penduga volume pohon menggunakan 101 pohon. Jumlah pohon sampel tersebut cukup representatif untuk menyusun model penduga volume pohon. Secara umum, pohon-pohon sampel mempunyai rataan standar deviasi yakni diameter $(\mathrm{cm}): 24,7 \pm 4,6$ dan tinggi (m): 18,0+1,8.

Pada tahap penyusunan model, pohon contoh yang digunakan mengelompok pada diameter antara 20-30 cm dan sedikit pada diameter lebih dari $40 \mathrm{~cm}$ sedangkan tinggi mengelompok pada kisaran antara 15-20 meter dan sedikit pada tinggi lebih dari 21 meter. Hal ini karena jenis nyawai yang ditemukan di lapangan paling banyak pada kisaran diameter dan tinggi tersebut.

\section{Penyelarasan model penduga volume}

Penyelarasan model penduga volume menggunakan diameter, tinggi, dan kombinasi tinggi dengan diameter sebagai peubah bebas. Penyelarasan beberapa model penduga ini menghasilkan koefisien determinasi yang besar $\left(\mathrm{R}^{2}>80 \%\right)$ (Tabel 1). Besarnya koefisien determinasi menunjukkan variasi peubah volume dapat dijelaskan oleh variasi peubah tidak bebas (diameter, tinggi, dan kombinasi diameter dengan tinggi). Parameter-parameter model dugaan sangat berpengaruh terhadap peubah tidak bebas $(\mathrm{p}<0,05)$. Pada hasil studi tersebut, model-model ini menggunakan peubah diameter dan tinggi secara bersama-sama. 
Tabel(Table) 1. Performansi model-model penduga volume pohon jenis nyawai (Performance of tree volume model of nyawai)

\begin{tabular}{|c|c|c|c|c|c|c|c|c|}
\hline \multirow{2}{*}{ Model } & \multicolumn{3}{|c|}{ Parameter } & \multirow{2}{*}{$\begin{array}{l}\mathrm{R}^{2} \\
(\%)\end{array}$} & \multirow{2}{*}{$\begin{array}{c}\mathrm{R}^{2} \text { adj } \\
(\%)\end{array}$} & \multirow{2}{*}{$\begin{array}{c}\mathrm{s} \\
\left(\mathrm{m}^{3}\right)\end{array}$} & \multirow{2}{*}{$\begin{array}{l}\text { SA } \\
(\%)\end{array}$} & \multirow{2}{*}{$\begin{array}{l}\text { SR } \\
(\%)\end{array}$} \\
\hline & $\mathrm{a}$ & $\mathrm{b}$ & c & & & & & \\
\hline E1 & 0,000690 & 2,0025 & & 93,01 & 92,89 & 0,06766 & $-0,99$ & 4,66 \\
\hline E2 & 0,101876 & 0,00003144 & & 92,90 & 92,78 & 0,0682 & $-1,82$ & 3,93 \\
\hline E3 & 0,106747 & 1,060342 & & 87,88 & 87,68 & 0,08908 & $-1,92$ & 5,22 \\
\hline E4 & $-0,293233$ & 0,01854484 & 0,00049 & 93,61 & 93,39 & 0,0652 & $-0,96$ & 4,77 \\
\hline E5 & 0,00018 & 1,678077 & 0,8315 & 94,31 & 94,11 & 0,06157 & $-2,38$ & 3,96 \\
\hline E6 & 6,3584 & 64,858 & & 93,13 & 93,01 & 0,06710 & $-1,23$ & 5,95 \\
\hline E7 & 0,10633 & 0,05872 & & 87,88 & 87,68 & 0,08908 & $-0,69$ & 7,96 \\
\hline E8 & 0,000186 & 0,83859 & & 94,33 & 94,24 & 0,06092 & $-2,39$ & 3,96 \\
\hline E9 & $-7,67757$ & 2,14025 & & 87,77 & 87,57 & 0,14811 & $-3,89$ & 5,21 \\
\hline E10 & $-9,10697$ & 1,77326 & 0,90385 & 90,45 & 90,13 & 0,13196 & $-0,60$ & 4,01 \\
\hline
\end{tabular}

Keterangan(Remarks): V: volume pohon total ( tree volum: $\left.\mathrm{m}^{3}\right) ; \mathrm{D}:$ Diameter $(\mathrm{cm}) ; \mathrm{H}$; tinggi pohon (height: $\left.\mathrm{m}\right) ; \mathrm{R}^{2}$ : koefisien determinasi (coefficient of determination: \%); $\mathrm{R}^{2}$ adj: koefisien determinasi terkoreksi coefficient of adjusted determination: \%) s: simpangan baku (standard deviation: $\mathrm{m}^{3}$ ); SR: simpangan Relatif (relative deviation: \%); SA: Simpangan Agregatif (Agregatif deviation: \%); a,b,c: parameter regresi (regression parameter)

Diameter sebagai peubah tunggal mendapatkan model penduga koefisien determinasi yang besar $\left(\mathrm{R}^{2}>80 \%\right)$ sehingga peubah diameter cu kup mampu menjelaskan variasi peubah volume pohon. Koefisien determinasi $\left(\mathrm{R}^{2}\right)$ yang dihasil kan oleh peubah tunggal (diameter) mencapai lebih dari 90\% (E1, E2, E4, dan E6).

\section{Penentuan model penduga terbaik}

Pada tahap akhir pemilihan model terbaik, model-model yang tidak memenuhi kriteria SA tidak dipilih sebagai calon model terbaik sehingga pada tahap ini, hanya model-model yang memenuhi seluruh kriteria menjadi calon model terbaik penduga volume jenis nyawai.
Penentuan model penduga volume terbaik menggunakan parameter lain yakni Standard error estimation, Akaike information criterion (AIC), Bias, dan Root Mean Square Erorrs (Tabel 2). Secara keseluruhan, model-model penduga volume yang terpilih menghasilkan simpangan dan variasi dugaan yang kecil. Hal ini menunjukkan tingkat akurasi dan ketepatan dugaan dari model tersebut sangat tinggi. Berdasarkan parameter AIC, model E4 merupakan model terbaik, tetapi model ini tidak selalu terbaik untuk seluruh kriteria statistik yang diterapkan. Berdasarkan fakta ini, pemilihan model terbaik dilakukan dengan pemberian skor pada masing-masing kriteria.

Tabel(Table) 2. Perkiraan standart deviasi (Standard eror estimation), Akaike information criterion (AIC), dan Root Mean Square Erorrs

\begin{tabular}{lcccccr}
\hline Model & $\begin{array}{c}\text { SEE } \\
\left(\mathrm{m}^{3}\right)\end{array}$ & $\begin{array}{c}\mathrm{AIC} \\
\left(\mathrm{m}^{3}\right)\end{array}$ & $\begin{array}{c}\text { RMSE } \\
(\%)\end{array}$ & $\begin{array}{c}\text { Bias } \\
(\%)\end{array}$ & $\begin{array}{c}\text { Total } \\
\text { skor }\end{array}$ \\
\hline E1: V $\quad 0,00073 \mathrm{D}^{2,0051}$ & 0,064 & 91,6 & 2,09 & 1,52 & 21 \\
E4: V $-0,19253 \quad 0,0128 \mathrm{D} \quad 0,0005 \mathrm{D}^{2}$ & 0,064 & 26,7 & 1,22 & 1,74 & 17 \\
E7: V $\quad 0,10633 * \exp 0,05872 \mathrm{D}$ & 0,155 & 89,1 & 5,93 & 5,11 & 28 \\
E10: $\ln \mathrm{-}-9,22846 \quad 1,7456 \ln (\mathrm{D})$ & $0,9759 \ln \mathrm{H}$ & $\mathbf{0 , 0 5 4}$ & $\mathbf{6 7 , 6}$ & $\mathbf{1 , 1 0}$ & $\mathbf{1 , 1 2}$ & $\mathbf{1 4}$ \\
\hline
\end{tabular}

Keterangan (Remarks): V:volume (tree volume: $\left.\mathrm{m}^{3}\right)$; D: diameter (diameter breast height: $\left.\mathrm{cm}\right) ; \mathrm{H}$ : tinggi (height: m); SEE: standard errors of estimation; RMSE: Root means square errors(\%); AIC: Akaike information criterion. 


\section{Potensi tegakan jenis nyawai}

Potensi tegakan ditentukan dari hasil inventarisasi pada beberapa umur yang berbeda. Potensi tegakan ditentukan menggunakan model penduga volume jenis nyawai terbaik. Potensi nyawai pada tegakan umur 4, 5, 6, dan 7 tahun berturutturut sebesar (rata-rata \pm stdev): $21,66 \pm 17,25$ (kisaran volume: $14,62-28,71) \mathrm{m}^{3} / \mathrm{ha} ; 24,20 \pm$ 10,91 (kisaran volume 17,90-30,51) $\mathrm{m}^{3} / \mathrm{ha}$; $38,84 \pm 1,76$ (kisaran volume $37,59-40,08)^{\mathrm{m}^{3}} /$ ha; dan 113,56 \pm 45,77 (kisaran volume: 94,88-132,24) $\mathrm{m}^{3} /$ ha. Hasil penentuan potensi tegakan dengan model terbaik menunjukkan besarnya potensi tegakan ini cenderung meningkat pada umur yang lebih sehingga potensi tegakan dipengaruhi oleh umur tanaman. Selain itu, besarnya potensi tegakan juga dipengaruhi oleh kerapatan tegakan.

\section{B. Pembahasan}

Banyaknya pohon sampel tersebut memadai untuk menyusun model penduga volume jenis nyawai. Menurut Loetsch et al., (1973) banyaknya pohon sampel dalam penyusunan model penduga volume minimal sebanyak 50-100 pohon. Pohon sampel mewakili sebaran diameter dan tinggi untuk jenis nyawai pada lokasi penelitian. Hubungan antara diameter dan tinggi tanaman dengan volume pohon menunjukkan hubungan yang positif. Hubungan ini ditunjukkan oleh tingginya koefisien korelasi (r). Nilai koefisien korelasi untuk diameter sebesar 0,96 dan tinggi sebesar 0,76. Umumnya, hubungan antara tinggi dan diameter dengan volume pohon mempunyai hubungan yang erat. Pada beberapa penelitian, nilai r yang didapatkan lebih dari 0,7 (Suchomel et al., 2012; Brassard et al., 2011; Zewdie et al., 2009, Turski et al., 2008).

Pada tahap penyelarasan model, koefisien determinasi yang dihasilkan lebih besar dari hasil studi yang dilakukan sebelumnya dengan metode yang sama (pengambilan sampel non destruktif). Hasil studi tersebut antara lain: jenis jelutung rawa dengan $\mathrm{R}^{2}=83,4 \%$ (Qirom dan Supriyadi, 2012b); jenis Acacia mangium, Mahohi, dan Gmelina dengan $\mathrm{R}^{2}$ berturut $74,6 \%$; $83,8 \%$; dan $83,9 \%$ (Susanty et al., 2006).

Secara umum, model-model yang mempunyai dua peubah bebas (diameter dan tinggi) secara bersama-sama atau kombinasi keduanya mempunyai $\mathrm{R}^{2}$ lebih besar dibandingkan dengan model yang menggunakan peubah bebas diameter. Model-model yang dihasilkan memiliki keakuratan yang tinggi. Hal ini ditunjukkan oleh nilai simpangan, simpangan agregatif dan relatif yang kecil. Secara keseluruhan, model-model yang telah disusun memenuhi kriteria simpangan relatif (SR $<10 \%)$. Namun demikian, sebagian besar model penduga volume tidak memenuhi kriteria simpangan agregatif $(\mathrm{SA}<1 \%)$. Modelmodel yang memenuhi kriteria SA yakni model E1, E4, E7, dan E10. Model-model tersebut umumnya menggunakan peubah diameter sebagai peubah bebas kecuali model E10. Kondisi ini menunjukkan peubah diameter cukup mampu menjelaskan variasi dari peubah volume pohon. Selain itu, penambahan peubah tinggi pohon tidak meningkatkan akurasi dugaan pohon secara agregat (bersama-sama) dari model penduga yang dihasilkan meskipun tingkat akurasi yang dihasilkan tidak berbeda jauh dari model dengan peubah tunggal.

Hasil skoring dari model-model dengan peubah diameter dan tinggi memperoleh skoring terkecil. Hal ini menunjukkan peubah tinggi berpengaruh terhadap peningkatan akurasi dan ketepatan dari model penduga volume. Model E10 adalah model terbaik berdasarkan hasil skoring dari seluruh kriteria yang digunakan (Tabel 10). Model ini mempunyai koefisien determinasi yang tinggi, simpangan dugaan yang kecil dan tingkat akurasi yang tinggi. Fenomena ini dapat dijelaskan oleh hubungan diameter dengan tinggi cukup erat yang ditunjukkan oleh koefisien korelasi (r) sebesar 0,722 (Gambar 3) dan hasil analisis korelasi menunjukkan kedua parameter berkorelasi positif $(p<0,05)$. 


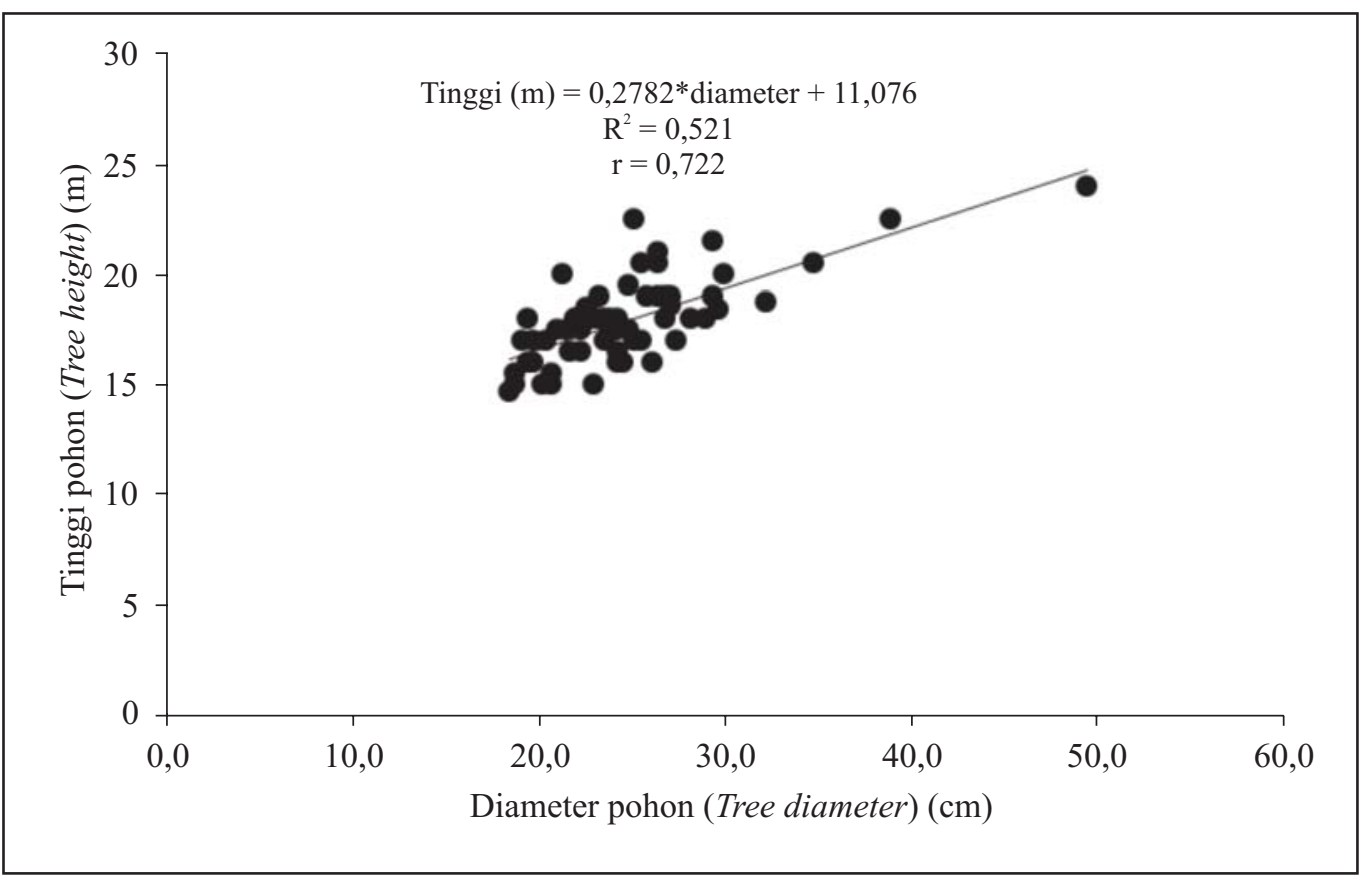

Gambar (Figure) 3. Hubungan diameter dengan tinggi tanaman (Diameter and tree height correlation)

Namun demikian, tingginya korelasi antar variabel bebas diameter dan tinggi meng-indikasikan adanya multikolinearitas antar kedua variabel tersebut. Berdasarkan hasil uji multi-kolinearitas diketahui kedua variabel bebas tersebut tidak terjadi multikolinearitas. Hal ini ditunjukkan oleh nilai Variance Inflation Factor (VIF) sebesar 1,91 dan secara parsial peubah diameter $\left(\mathrm{t}_{(0,025 ; 60)}=13,66 ; \mathrm{p}_{\text {value }}<0,05\right)$ dan tinggi $\left(\mathrm{t}_{(0,025 ; 60)}=\right.$ 4,$\left.04 ; \mathrm{p}_{\text {value }}<0,05\right)$ berpengaruh nyata terhadap peubah volumenya.

Berdasarkan uji tersebut, model penduga dengan peubah bebas diameter dan tinggi (E10): $L n$ Volume $=-9,22846+1,7456$ Ln (Diameter) + 0,9757 Ln (tinggi) digunakan untuk menyusun tabel volume pohon total jenis nyawai. Tabel volume standar disusun dengan memasukkan diameter dan tinggi hasil pengukuran di lapangan pada model terbaik terpilih. Tabel volume ini seperti pada Lampiran 1. Berdasarkan pertimbangan kepraktisan dan akurasi model yang dihasilkan, model penduga volume dengan peubah diameter dapat digunakan untuk pendugaan volume jenis nyawai. Hal ini dikarenakan penambahan tinggi hanya meningkatkan besarnya nilai koefisien determinasi sebesar $1,32 \%$ terhadap besarnya koefisien determinasi maksimum dari model dengan peubah tunggal (diameter). Dari hasil tersebut, penggunaan diameter dalam menduga volume pohon lebih menguntungkan. Hal ini karena pengambilan data tinggi di lapangan membutuhkan waktu dan biaya yang lebih besar (Zewdie et al., 2009). Pada prakteknya, pengambilan data diameter di lapangan lebih mudah dan murah dengan tingkat akurasi yang tinggi (Zewdie et al., 2009). Model dengan peubah diameter yang akan digunakan untuk menduga volume harus memenuhi kriteria kelogisan model. Kelogisan model tersebut dengan menggunakan kurva prediksi menggunakan model E1, E4, dan E7 (Gambar 4). Berdasarkan kurva tersebut model E4 tidak dapat digunakan untuk menduga volume pohon nyawai terutama pohon-pohon nyawai dengan diameter kurang dari $13 \mathrm{~cm}$ sehingga model yang akan digunakan untuk penyusunan tabel volume lokal yakni model E1 dan E7. Model E1 dan E7 memenuhi kriteria kelogisan model namun model E1 mempunyai koefisien determinasi yang lebih besar dan tingkat ketepatan serta akurasi yang cukup tinggi dibandingkan E7. Berdasarkan pertimbangan tersebut, model E1 digunakan untuk menyusun tabel volume lokal jenis nyawai (Lampiran 2). 


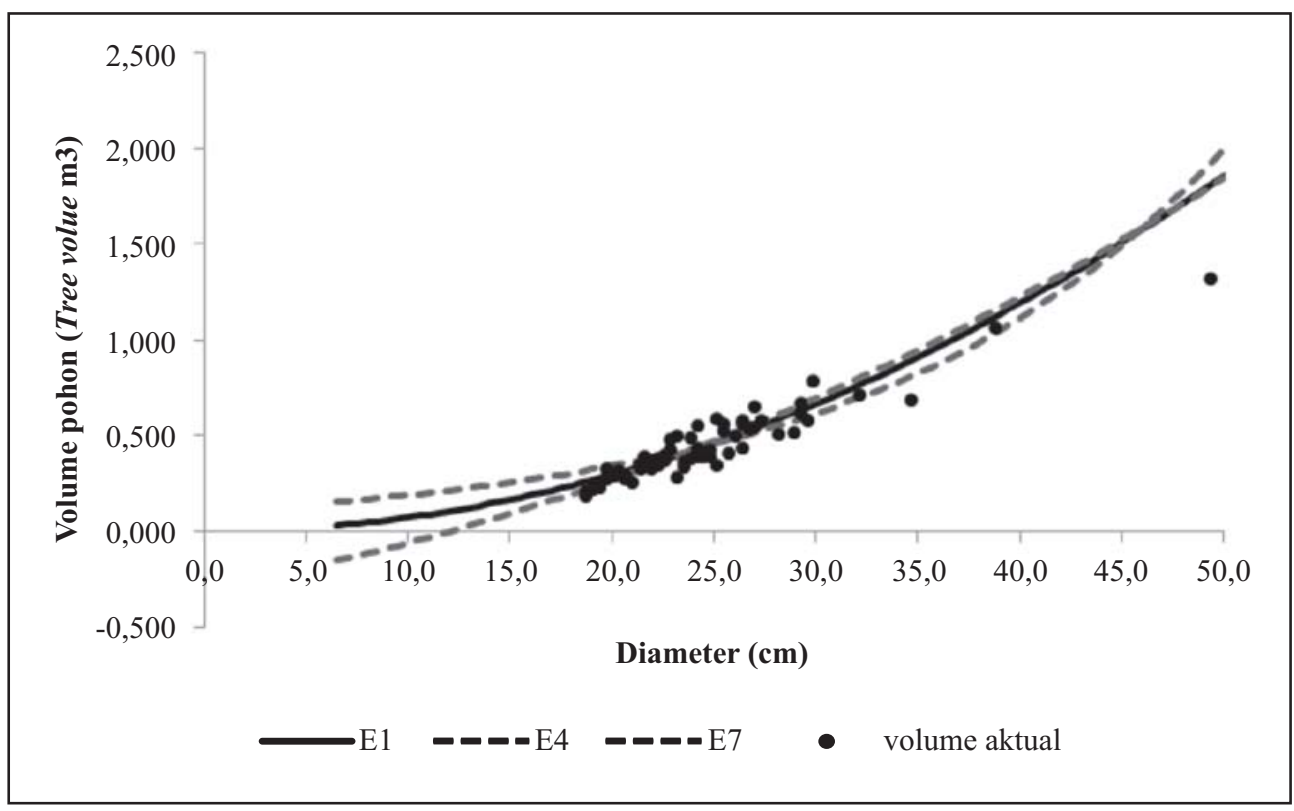

Gambar(Figure) 4. Pendugaan volume pohon berdasarkan model dengan peubah bebas diameter (Tree volume prediction based on single variable)

\section{KESIMPULAN}

\section{A. Kesimpulan} bahwa:

Dari hasil penelitian ini dapat disimpulkan

1. Pendugaan volume pohon jenis nyawai menggunakan dua peubah tinggi dan diameter atau kombinasi antara tinggi dengan diameter mempunyai tingkat akurasi yang lebih tinggi dibandingkan model penduga yang menggunakan diameter sebagai peubah tunggal.

2. Model terbaik penduga volume yaknimodel dengan peubah diameter dan tinggi. Model tersebut adalah: Ln Volume $=-9,22846+$ 1,7456 Ln (Diameter) + 0,9757 Ln (tinggi) dengan koefisien determinasi sebesar 90,45\%.

3. Penggunaan variabel tinggi harus dipertimbangkan karena pengukuran tinggi di lapangan dapat menimbulkan bias dan membutuhkan waktu serta biaya yang besar dalam inventarisasi. Penggunaan diameter sebagai peubah tunggal dapat dipertimbang-kan untuk digunakan. Hal ini karena tingkat akurasi dan ketepatan model penduga volume pohon dengan peubah tunggal diameter cukup tinggi.

\section{B. Saran}

Tabel volume dengan variabel diameter seba- gai peubah tunggal hanya dapat digunakan pada kondisi iklim dan tempat tumbuh yang sama.

\section{UCAPAN TERIMAKASIH}

Penelitian ini didukung oleh pendanaan DIPA Balai Penelitian Kehutanan Banjarbaru tahun 2012. Penulis mengucapkan terimakasih kepada Kepala Balai Penelitian Kehutanan Banjarbaru atas kepercayaan dan dukungannya dalam melaksanakan kegiatan penelitian Evaluasi dan Prediksi Pertumbuhan dan Hasil Jenis Jelutung Rawa dan nyawai. Penulis juga mengucapkan terimakasih kepada seluruh Manajemen PT. ITCIKartika Utama Kalimantan Timur atas segala fasilitas, dukungan, dan ijin melaksanakan penelitian di areal perusahaan.

\section{DAFTAR PUSTAKA}

Akinnifesi, F.K. and F.A. Akinsami. 1995. Linear Equation for Estimating the Merchantable Wood Volume of Gmelina arborea in Southwest Nigeria. Journal of Tropical Science1995: Volume 7 No. 3: 391-397.

Arevalo C.B.M., T. A. Volk, E. Bevilacqua, and L. Abrahamson. 2007. Development and Validation of Aboveground Biomass Estimations for four Salix Clones in central New York. Biomass and Bioenergy 31: 1-12. 
Badan Litbang Kehutanan. 2010. Rencana Penelitian Integratif(RPI) 2010-2014. Jakarta.

Basuki, T.M., P.E. van Laake, A.K. Skidmore, and Y.A. Hussin. 2009. Allometric Equations for Estimating the Aboveground Biomass in Tropical Lowland Dipterocarp Forests. Forest Ecology and Management 257:1684-1694.

Bitterlich, W. 1990. A Comprehensive Concept of Tree and Stand Measurements. Proceedings from Session S4.01 Mensuration, Growth and Yield at the world congress of the IUFRO. Montreal, Canada. August 5-11. Pp 1 - 12. Http://online. anu.edu.au/Forestry/mensuration/RELAKOP.HTML.

Brandies, T.J., M. Delaney, B.R. Parresol, and L. Royer. 2006. Development of Equations for Predicting Puerto Rican Subtropical Dry Forest Biomass and Volume. Forest Ecology and Management 233: 133-142.

Brassard, B.W., H.Y.H. Chen, Y. Bergeron, and D. Pare. 2011. Coarse Root Biomass Allometric Equations for Abies balsamea, Picea mariana, Pinus banksiana, and Populus tremuloides in the Boreal Forest of Ontario, Canada. Biomass and Bioenergy 35: 4189-4196.

Brown, S., A.J.R. Gillespie and AE. Lugo. 1989. Aboveground Biomass Estimate for Tropical Moist Forest of the Brazilian Amazon. Interciencia 17: 8-18.

Brown, S. 1997. Estimating Biomass and Biomass Change of Tropical Forest: a Primer. Rome, Italy: FAO Forestry Paper 134.

Husch, B. 1963. Forest Mensuration and Statistics. The Roland Press Company. New York.

Kuaraksa, C., S. Elliott and M. Hossaert-Mckey. 2012. The Phenology of Dioecious Ficus spp. Tree Species and Its Importance for Forest Restoration Projects. Forest Ecology and Management 265: 82-93

Laar, V. and A. Akça. 1997. Forest Mensuration. Cuvillier Verlag. Gottingen. 418p.

Loetsch, F., F. Zohrer F., and K.E. Haller KE. 1973. Forest inventory. Verlagsgesellschaft. BLV. Munich. 469 pp.

Lima, A.J.N., R. Suwa, G.H.P.M. Ribeiro, T. Kajimoto, J. dos Santos, R.P. da Silva, C.A.S. de Souza, P.C. de Barros, H. Noguchi, M. Ishizuka, and N. Higuchi. 2012. Allometric Models for Estimating Above and Below-ground Biomass in Amazonian Forests at Sao Gabriel da Cachoeira in the Upper Rio Negro, Brazil. Forest Ecology and Management 277: 163-172.

Montagu, K.D., K. Duttmer, C.V.M. Barton and A.L. Cowie. 2005. Developing General Allometric Relationships for Regional Estimates of Carbon Sequestrationan Example using Eucalyptus pilularis from seven contrasting sites.
Forest Ecology and Management 204:113127.

Peng, C. 2000. Growth and Yield Models for Unevenaged Stands: Past, Present and Future. Forest Ecology and Management 132: 259-279.

Qirom M.A. dan Supriyadi. 2012a. Evaluasi dan Prediksi Pertumbuhan dan hasil Jenis Jelutung Rawa dan Nyawai. Laporan Hasil Penelitian. Balai Penelitian Kehutanan Banjarbaru.

Qirom M.A. dan Supriyadi. 2012b. Penyusunan Model Penduga Volume Pohon Jenis Jelutung Rawa (Dyera polyphylla (Miq) V. Steenis). Jurnal Hutan Tanaman Vol 9 No. 3: 141-153.

Suchomel, C., P. Pyttel, G. Becker, and J. Bauhus. 2012. Biomass Equations for Sessile Oak (Quercus petraea (Matt.) Liebl.) and hornbeam (Carpinus betulus L.) in Aged Coppiced Forests in Southwest Germany. Biomass and Bioenergy 46: 722-730.

Snorrason, A. and S.F. Einarsson. 2006. Single-tree Biomass and Stem Volume Functions for Eleven Tree Species used in Icelandic Forestry. ICEL.AGRIC. SCI. 19: 15-24.

Spurr, SH. 1952. Forest inventory. The Ronald Press Company. United States of America.

Spencer, H, G. Weiblen and B. Flick. 1996. Phenology of Ficus variegata in a Seasonal Wet Tropical Forest at Cape Tribulation, Australia. Journal of Biogeography, Vol. 23, No. 4: 467-475.

Subedi, M.R., and R.P. Sharma. 2012. Allometric Biomass Models for Bark of Cinnamomum tamala in Mid-Hill of Nepal. Biomass and Bioenergy 47: 44-49.

Susanty, F.H, A. Supriyanto, M. Budiono, dan D. Suprayitno. 2006. Analisis Model Pendugaan Volume Jenis Acacia mangium, Gmelina arborea, dan Swietenia mahagoni di Hutan Tanaman. Prosiding Seminar Bersama Hasilhasil Penelitian Tanggal 12 April 2006. Samarinda.

Turski, M., C. Beker, K. Kazmierczak and T. Najgrakowski. 2008. Allometric Equations for Estimating the Mass and Volume of Fresh Assimilational Apparatus of Standing Scots Pine (Pinus sylvestris L.) Trees. Forest Ecology and Management (255):2678-2687.

Zewdie, M., M. Olsson, and T. Verwijst. 2009. Aboveground Biomass Production and Allometric Relations of Eucalyptus globulus Labill. Coppice Plantations along a Chronosequence in the Central Highlands of Ethiopia. Biomass and Bioenergy 33: 421-428.

Zianis, M., P. Muukkonen, R. Makipaa and M. Mencuccini. 2005. Biomass and Stem Volume Equations for Tree Species in Europe. Silva Fennica Monographs 4. The Finnish Forest Research Institute. 
Lampiran (Appendix) 1. Tabel volume standar jenis F. variegata (The standard of tree volume table of F. Variegata)

\begin{tabular}{|c|c|c|c|c|c|c|c|c|c|c|c|c|c|}
\hline \multirow{2}{*}{$\begin{array}{l}\text { DBH } \\
(\mathrm{cm})\end{array}$} & \multicolumn{13}{|c|}{ Tinggi $($ Height $)$} \\
\hline & 10 & 11 & 12 & 13 & 14 & 15 & 16 & 17 & 18 & 19 & 20 & 21 & 22 \\
\hline 14 & 0,093 & 0,102 & 0,111 & 0,120 & 0,129 & 0,138 & 0,147 & 0,156 & 0,165 & 0,174 & 0,183 & 0,192 & 0,201 \\
\hline 15 & 0,105 & 115 & 0,125 & 136 & 146 & 0,156 & 0,166 & 0,176 & 0,186 & 0,196 & 0,206 & 0,217 & 0,227 \\
\hline 16 & 0,117 & 0,129 & 0,140 &, 152 & 163 & 0,174 & 0,186 & 0,197 & 0,208 & 0,220 & 0,231 & 0,242 & 0,254 \\
\hline 17 & 0,131 & 0,143 & 0,156 & 169 & 181 & 0,194 & 0,207 & 0,219 & 0,232 & 0,244 & 0,257 & 0,269 & 0,282 \\
\hline 18 & 144 & 0,158 & 0,172 &, 186 & 200 & 0,214 & 0,228 & 0,242 & 0,256 & 0,270 & 0,284 & 0,298 & 0,311 \\
\hline 19 & 0,159 & 0,174 & 0,189 & 205 & 0,220 & 0,236 & 0,251 & 0,266 & 0,281 & 0,297 & 0,312 & 0,327 & 0,342 \\
\hline 20 & & & 0,20 & & 241 & 0,2 & 0,2 & 0,291 & 08 & 0,324 & 0,3 & 0,3 & 0,374 \\
\hline 21 & & 0,2 & 0,22 & & 0,262 & 0,281 & 0,2 & 0,3 & 0,3 & 0,353 & 0,3 & 0,3 & 0,408 \\
\hline 22 & & 0,2 & 0,245 & 5 & 34 & 0,3 & 0,3 & 0,3 & 0,3 & 0,3 & & 0,4 & 0,442 \\
\hline 23 & 0,221 & 0,2 & 0,264 & 0,28 & 0,307 & 0,329 & 0,3 & 0,3 & 0,39 & 0,414 & 0,4 & 0,4 & 0,478 \\
\hline 24 & 38 & 0,262 & 0,285 & ,308 & 331 & 0,354 & 0,377 & 0,400 & 23 & 0,446 & 0,469 & 0,4 & 0,515 \\
\hline 25 & & & & & & & & 0,4 & 0,454 & & 0,504 & 0,5 & 0,553 \\
\hline 26 & 0,274 & 0,301 & 0,328 & 0,354 & 0,381 & 0,407 & 0,434 & 0,460 & 0,487 & 0,513 & 0,539 & 0,566 & 0,592 \\
\hline 27 & & & & & & & & 0,491 & 0,520 & & 0,5 & 0,604 & 0,632 \\
\hline 28 & 0,312 & 0,342 & 0,373 & 0,403 & 0,433 & 0,463 & 0,494 & 0,524 & 0,554 & 0,584 & 0,614 & 0,644 & 0,674 \\
\hline 29 & & & 0,396 & & 0,461 & & 0,525 & 0,557 & 0,589 & 0,621 & 0,652 & 0,684 & 0,716 \\
\hline 30 & 0,352 & 0,386 & 0,421 & 0,455 & 0,489 & 0,523 & 0,557 & 0,591 & 0,625 & 0,658 & 0,692 & 0,726 & 0,760 \\
\hline 31 & & & & & & & & & & & & & 0,804 \\
\hline 32 & 0,394 & 0,432 & 0,471 & 0,509 & 0,547 & 0,585 & 0,623 & 0,661 & 0,699 & 0,737 & 0,775 & 0,813 & 0,850 \\
\hline 33 & & & & & & & 0,658 & & & & & 0,857 & 0,897 \\
\hline 34 & 0,438 & 0,481 & 0,523 & 0,566 & 0,608 & 0,650 & 0,693 & 0,735 & 0,777 & 0,819 & 0,861 & 0,903 & 0,945 \\
\hline 35 & 0,461 & 0,506 & 0,550 & 0,595 & 0,640 & 0,684 & 0,729 & 0,773 & 0,817 & 0,862 & 0,906 & 0,950 & 0,994 \\
\hline
\end{tabular}

Keterangan (Remarks): DBH: diameter setinggi dada (diameter breast height:cm); V: volume pohon (tree volume: $\mathrm{m}^{3}$ ) 
Lampiran (Appendix) 2. Tabel volume lokal jenis $F$. variegata (The local volume table of $\mathrm{F}$. Variegata)

\begin{tabular}{cccccccc}
\hline $\begin{array}{c}\text { DBH } \\
(\mathrm{cm})\end{array}$ & $\begin{array}{c}\text { Volume } \\
\left(\mathrm{m}^{3}\right)\end{array}$ & $\begin{array}{c}\text { DBH } \\
(\mathrm{cm})\end{array}$ & $\begin{array}{c}\text { Volume } \\
\left(\mathrm{m}^{3}\right)\end{array}$ & $\begin{array}{c}\text { DBH } \\
(\mathrm{cm})\end{array}$ & $\begin{array}{c}\text { Volume } \\
\left(\mathrm{m}^{3}\right)\end{array}$ & $\begin{array}{c}\text { DBH } \\
(\mathrm{cm})\end{array}$ & $\begin{array}{c}\text { Volume } \\
\left(\mathrm{m}^{3}\right)\end{array}$ \\
\hline 6,5 & 0,0312 & 15,5 & 0,1781 & 24,5 & 0,4459 & 33,5 & 0,8351 \\
7,0 & 0,0362 & 16,0 & 0,1898 & 25,0 & 0,4644 & 34,0 & 0,8602 \\
7,5 & 0,0415 & 16,5 & 0,2019 & 25,5 & 0,4832 & 34,5 & 0,8858 \\
8,0 & 0,0473 & 17,0 & 0,2143 & 26,0 & 0,5024 & 35,0 & 0,9117 \\
8,5 & 0,0534 & 17,5 & 0,2271 & 26,5 & 0,5219 & 35,5 & 0,938 \\
9,0 & 0,0599 & 18,0 & 0,2403 & 27,0 & 0,5418 & 36,0 & 0,9647 \\
9,5 & 0,0667 & 18,5 & 0,2539 & 27,5 & 0,5622 & 36,5 & 0,9917 \\
10,0 & 0,074 & 19,0 & 0,2678 & 28,0 & 0,5828 & 37,0 & 1,0192 \\
10,5 & 0,0816 & 19,5 & 0,2822 & 28,5 & 0,6039 & 37,5 & 1,047 \\
11,0 & 0,0895 & 20,0 & 0,2969 & 29,0 & 0,6253 & 38,0 & 1,0751 \\
11,5 & 0,0979 & 20,5 & 0,3119 & 29,5 & 0,6471 & 38,5 & 1,1037 \\
12,0 & 0,1066 & 21,0 & 0,3274 & 30,0 & 0,6693 & 39,0 & 1,1326 \\
12,5 & 0,1157 & 21,5 & 0,3432 & 30,5 & 0,6919 & 39,5 & 1,1619 \\
13,0 & 0,1252 & 22,0 & 0,3594 & 31,0 & 0,7148 & 40,0 & 1,1916 \\
13,5 & 0,135 & 22,5 & 0,3759 & 31,5 & 0,7381 & 40,5 & 1,2217 \\
14,0 & 0,1452 & 23,0 & 0,3929 & 32,0 & 0,7618 & 41,0 & 1,2521 \\
14,5 & 0,1558 & 23,5 & 0,4102 & 32,5 & 0,7858 & 41,5 & 1,2829 \\
15,0 & 0,1667 & 24,0 & 0,4279 & 33,0 & 0,8103 & 42,0 & 1,3141 \\
\hline
\end{tabular}

Keterangan (Remarks): DBH: diameter setinggi dada (diameter breast height: $\mathrm{cm}) ; \mathrm{V}$ : volume pohon (tree volume: $\mathrm{m}^{3}$ ) 